\title{
Effect of Ethanol Leaf Extract of Vernonia amygdalina on Some Indices of Liver, Kidney Function and Lipid Profile in Theobromine Intoxicated Male Albino Wistar Rats
}

\author{
Edet Okon Akpanyung, ", Utibe Evans Bassey ${ }^{2}$, Emem Ekpenyong Udofia ${ }^{1}$, \\ Grace Sylvester Effiong ${ }^{1}$ \\ ${ }^{1}$ Department of Biochemistry, Faculty of Basic Medical Sciences, University of Uyo, Uyo, Nigeria \\ ${ }^{2}$ Department of Biochemistry, Faculty of Natural and Applied Sciences, Obong University, Etim Ekpo, Nigeria \\ Email address: \\ edetakpanyung@gmail.com (E. O. Akpanyung) \\ ${ }^{*}$ Corresponding author
}

\section{To cite this article:}

Edet Okon Akpanyung, Utibe Evans Bassey, Emem Ekpenyong Udofia, Grace Sylvester Effiong. Effect of Ethanol Leaf Extract of Vernonia amygdalina on Some Indices of Liver, Kidney Function and Lipid Profile in Theobromine Intoxicated Male Albino Wistar Rats. Journal of Food and Nutrition Sciences. Vol. 6, No. 4, 2018, pp. 106-114. doi: 10.11648/j.jfns.20180604.13

Received: August 6, 2018; Accepted: August 21, 2018; Published: September 26, 2018

\begin{abstract}
The effect of ethanol leaf extract of Vernonia amygdalina on some indices of liver, kidney function and lipid profile in male albino Wistar rats intoxicated with theobromine was investigated. Thirty (30) male Wistar rats weighing between $140 \mathrm{~g}-160 \mathrm{~g}$ used for the study were divided into 6 groups with 5 animals in each group. Group I served as control while Group 2 received $700 \mathrm{mg} / \mathrm{kg}$ bw of theobromine daily for 4 days. Group 3 received $400 \mathrm{mg} / \mathrm{kg}$ bw of $V$. amygdalina leaf extract daily for 21 days while Groups 4 and 5 were treated with $400 \mathrm{mg} / \mathrm{kg}$ bw of $V$. amygdalina leaf extract for 21 days before and after intoxication with $700 \mathrm{mg} / \mathrm{kg}$ bw of theobromine for 4 days respectively. Group 6 was given $700 \mathrm{mg} / \mathrm{kg}$ bw of theobromine daily for 4 days and then allowed for 21 days without treatment. Serum was obtained from whole blood and used to determine activities of some serum enzymes and lipid profile as well as kidney function. The liver, kidney and heart were excised and used for histological studies. The results show significantly increased serum enzyme activities, total cholesterol and LDL cholesterol concentration in Group 2 compared to the control $(\mathrm{P}<0.05)$. HDL cholesterol was significantly decreased in theobromine treated group when compared to Group $1(\mathrm{P}<0.05)$. Administration of $V$. amygdalina leaf extract alone showed results close to those of the control. Group 4 showed decreased serum enzyme activities, decreased concentration of total cholesterol and LDL cholesterol while HDL cholesterol was increased significantly when compared to Group 2. Group 5 also showed a significant difference in the biochemical indices when compared to Group 2 while Group 6 show decreased serum enzyme activity that was significant when compared to Group 2. The urea and creatinine concentrations were significantly increased in theobromine intoxicated animals while administration of Vernonia amygdalina normalised these parameters. Histology of the liver, kidney and heart revealed altered cellular architecture following administration of theobromine (Group 2) while normal histological features were restored after treatment with ethanol leaf extract of $V$. amygdalina. The study has demonstrated that ethanol leaf extract of Vernonia amygdalina ameliorate and protect liver, kidney and heart of male albino Wistar rats against theobromine induced toxicity and modulates the adverse effects on lipid profile.
\end{abstract}

Keywords: Vernonia amygdalina, Theobromine Toxicity, Lipid Profile, Liver Enzyme Activities, Kidney Function

\section{Introduction}

Vernonia amygdalina, commonly called bitterleaf, is a shrub, $2-5$ meters in height with petiolate green leaves of about $6 \mathrm{~mm}$ diameter [1]. It thrives on a wide range of ecological zones such as Afro-montane rainforest, evergreen bush land and sometimes forming clumps in upland wooded grassland as well as in lowland humid rangeland, savannah 
and riverine fringes. In many parts of Africa, the plant has been domesticated [2], and used as hedge plant in some communities [3]. The leaf of $V$. amygdalina is widely consumed as vegetable for its rich array of nutritional components and phytochemicals which are responsible for the various health and medicinal benefits attributed to Vernonia amygdalina. The proximate composition of $V$. amygdalina has revealed significant quantities of lipids [4, 5], proteins with high essential amino acid score $[6,5]$ that compare favourably with values reported for Telfairia occidentalis and Talinum triangulare [7], carbohydrates [4] and fibre [5]. The plant has also been shown to contain appreciable quantities of ascorbic acid, carotenoids [6, 4], calcium, iron, potassium, phosphorous, manganese, copper and cobalt [3-5].

Nwanjo [8], reported that the aqueous leaf extract of $V$. amygdalina reduced triacylglycerol levels and normalized cholesterol concentrations in the serum of diabetic rats. The ethanol leaf extract of the plant has also been reported to maintain the lipid profile of rats within normal range (taken as that of the control rats) when doses of $100-1000 \mathrm{mg} / \mathrm{kg}$ body weight were administered [9]. It has been reported that Vernonia amygdalina has cardio-protective potential in Streptozocin (STZ) induced diabetic rats [10]. These authors [10] observed that the leaf extract of Vernonia amygdalina could protect the heart against impairment and complete destruction due to diabetes. Furthermore, Arhoghro et al. [11] reported that Vernonia amygdalina protected against and also reversed the hepatic damage caused by tetrachloromethane-induced hepatotoxicity in albino rats. Iwalokun et al. [12] also support the hepatoprotective effect of Vernonia amygdalina in rats. Ethanol leaf extract of Vernonia amygdalina has been reported to protect against kidney impairment [13]. Due to its numerous medicinal benefits, the leaf of Vernonia amygdalina has found wide application in various aspects of traditional medicine including its usage in the amelioration of toxic effects of chemical substances.

Theobromine is the primary bitter-tasting alkaloid found in cocoa and chocolate. It has been reported to be toxic with oral $\mathrm{LD}_{50}$ in the range of $950 \mathrm{mg} / \mathrm{kg}$ and $1356 \mathrm{mg} / \mathrm{kg}$ body weight in rats and mice, respectively [14]. Eteng et al., [15], reported that theobromine induces cardiotoxicity in experimental animals which was evident in increased alanine aminotransferase (ALT) and aspartate aminotransferase (AST) activities in serum. Histological evaluation of the heart of the experimental animals further proved that theobromine induces damage to the heart. Adeyina et al., [16] also carried out studies on the comparative effect of theobromine and cocoa bean shell (CBS) extract on serum enzyme activities in rabbits. Increase in the value of serum alkaline phosphate (ALP) and AST activities in rabbits administered theobromine was reported. The increase in ALP and AST was attributed to theobromine toxicity affecting the liver with subsequent breakdown in membrane architecture of the cells leading to spillage of the enzymes into the serum [17].
In view of the toxic effects of theobromine and the medicinal potentials of Vernonia amygdalina, the present study therefore evaluated the effect of ethanol leaf extract of Vernonia amygdalina on the heart, liver and kidney of theobromine intoxicated male albino rats.

\section{Materials and Methods}

\subsection{Sources of Theobromine and Vernonia amygdalina Leaf}

Pure synthetic theobromine was obtained from $\mathrm{BDH}$ chemicals, Poole, England and it had physical characteristics identical to those of naturally occurring compounds in cocoa bean seeds. Fresh leaves of Vernonia amygdalina were procured from a local market in Uyo, Akwa Ibom State, Nigeria. They were authenticated by the curator of the Herbarium, Department of Botany, University of Uyo, Uyo, Nigeria.

\subsection{Experimental Animals}

Thirty (30) male albino Wistar rats weighing between $140-160 \mathrm{~g}$ were obtained from the Animal House, Faculty of Basic Medical Sciences, University of Uyo, Uyo, Nigeria. The animals were housed in a well-ventilated room and maintained under standard natural photoperiodic condition of twelve (12) hours of light alternating with twelve (12) hours of darkness. The animals were fed with rat chow and clean drinking water ad libitum and allowed to acclimatize over a period of two weeks prior to the commencement of the experiment. Handling of animals was based on the international standard protocol and care for experimental animals [18]. Institutional approval for the study was obtained from the Research Ethical Committee, College of Health Science, University of Uyo, Uyo, Nigeria.

\subsection{Preparation of Vernonia amygdalina Leaf Extract}

Fresh leaves of $V$. amygdalina were sorted and washed to remove debris and dust particles. The leaves were air dried at room temperature for two weeks after which they were ground into powder. The powdered sample $(585 \mathrm{~g})$ was macerated in $80 \%$ ethanol for 48 hours. The mixture was then filtered with Whatman No. 1 filter paper to obtain a homogenous filtrate. The filtrate was concentrated in a water bath at $40^{\circ} \mathrm{C}$ to obtain the crude extract. The extract was stored in a refrigerator at $4^{\circ} \mathrm{C}$.

\subsection{Experimental Design}

The thirty (30) male albino rats were randomly selected into six (6) groups with five rats per group. Group I served as control while Group 2 received $700 \mathrm{mg} / \mathrm{kg}$ bw of theobromine daily for 4 days. Group 3 received $400 \mathrm{mg} / \mathrm{kg}$ bw of $V$. amygdalina leaf extract daily for 21 days while Groups 4 and 5 were treated with $400 \mathrm{mg} / \mathrm{kg} \mathrm{bw}$ of $V$. amygdalina leaf extract for 21 days before and after 
intoxication with $700 \mathrm{mg} / \mathrm{kg}$ bw of theobromine for 4 days respectively. Group 6 was given $700 \mathrm{mg} / \mathrm{kg}$ bw of theobromine daily for 4 days and then allowed 21 days recovery period.

The animals were fasted overnight after the last administration of the extract and sacrificed under chloroform anaesthesia. Blood sample was collected through cardiac puncture using sterile syringes and needles into labelled sample bottles. The blood was allowed to clot and serum was obtained by centrifugation at $3000 \mathrm{rpm}$ for 15 minutes using a bench top centrifuge. The heart, liver and kidney of the experimental animals were excised and preserved in $10 \%$ buffered formalin for histological studies.

\subsection{Estimation of Biochemical Parameters}

Serum ALT activity was assayed based on the method developed by Wroblewski and Ladue [19], while the method of Doumas and Briggs [20], was used to assay AST activity. The method of Bowers and McComb [21] was used to estimate ALP activity in the serum. Lipid profile comprising total cholesterol, triglyceride, HDL-cholesterol was determined using the methods of Allain et al., [22], Lopez et al., [23], and Tietz [24]. LDL-cholesterol and VLDLcholesterol were calculated accordingly using the Friedewald formula [25]. Serum urea was determined using kinetic method [26]. The assay of creatinine was based on the colorimetric method of Jaffe as described by Heinegard and Tinderstrom [27].

\subsection{Histopathological Studies}

Three animals were selected randomly from each group and dissected through a central abdominal incision. The livers and hearts were harvested and processed for histological studies as described by Akpanyung et al., [28]. Organ sections were passed through the processes of fixation, dehydration, clearing, infiltration, embedding, sectioning and staining with haematoxylin and $\operatorname{eosin}(\mathrm{H}$ and $\mathrm{E})$ for examination under a light microscope. Photomicrographs of some of the tissue sections were taken using a digital camera fitted to the light microscope at a magnification of $\mathrm{x} 100$.

\subsection{Statistical Analysis}

The data obtained were expressed as mean \pm standard error of mean (SEM). One-Way analysis of variance (ANOVA) was used for comparison and results were subjected to post hoc test using Tukey multiple comparison. Test values of $\mathrm{p}<$ 0.05 were considered significant.

\section{Results}

The effect of ethanol leaf extract of Vernonia amygdalina on lipid profile, liver and kidney function of albino Wistar rats intoxicated with theobromine is presented in Tables 1, 2 and 3 respectively. Theobromine is observed to significantly $(\mathrm{P}<0.05)$ increase total cholesterol and LDL cholesterol in Group 2 when compared to Group 1. Administration of the extract significantly reduced the cholesterol level when compared to Group 2. HDL-C increased in the treated groups except theobromine treated group. The histology of the heart revealed normal cytoarchitecture with obvious cardiac muscles in the control group while the theobromine intoxicated group (Group 2) showed haemorrhagic regions in the myocardium as well as cellular degeneration. The Vernonia amygdalina treated groups showed normal histological features of the heart while Group 6 revealed congested blood vessels and inflammation of the pericardium.

Significant decreases $(\mathrm{P}<0.05)$ in ALT, AST and ALP were observed in Groups 3, 4 and 5 when compared to Group 1 and 2 while Group 6 was significantly decreased compared to Group 2 but not to the extent of the treated groups. The histology of the liver collaborates the results from biochemical parameters. Normal histological features were observed in the control group while cellular degeneration and congestion of central portal vein was observed in the theobromine intoxicated group. Administration of Vernonia amygdalina showed amelioration of the toxic effect of theobromine while toxicity was still observed in Group 6.

Table 1. Effect of Ethanol Leaf Extract of Vernonia amygdalina on Lipid Profile of Albino Wistar Rats Intoxicated with Theobromine.

\begin{tabular}{|c|c|c|c|c|c|}
\hline GROUPS & TCHOL (mmol/L) & TG $(\mathrm{mmol} / \mathrm{L})$ & HDL-C (mmol/L) & LDL-C (mmol/L) & VLDL-C (mmol/L) \\
\hline Group 1 - Control & $2.34 \pm 0.04$ & $1.38 \pm 0.03$ & $1.15 \pm 0.04$ & $0.57 \pm 0.08$ & $0.63 \pm 0.01$ \\
\hline Group 2 - Theobromine & $3.05 \pm 0.29^{\mathrm{a}}$ & $1.24 \pm 0.12$ & $0.91 \pm 0.03^{\mathrm{a}}$ & $1.58 \pm 0.29^{\mathrm{a}}$ & $0.56 \pm 0.06$ \\
\hline Group 3 - V. amygdalina & $2.38 \pm 0.17^{b}$ & $1.51 \pm 0.25$ & $1.31 \pm 0.04^{\mathrm{ab}}$ & $0.46 \pm 0.13^{\mathrm{b}}$ & $0.61 \pm 0.05$ \\
\hline Group 4 - Theobromine Then $V$. amygdalina & $2.11 \pm 0.11^{\mathrm{b}}$ & $1.28 \pm 0.04$ & $1.02 \pm 0.03$ & $0.51 \pm 0.09^{b}$ & $0.48 \pm 0.11$ \\
\hline Group 5 - V. amygdalina Then Theobromine & $1.88 \pm 0.08^{\mathrm{abc}}$ & $1.09 \pm 0.04$ & $0.91 \pm 0.05^{\mathrm{a}}$ & $0.54 \pm 0.05^{\mathrm{b}}$ & $0.49 \pm 0.02$ \\
\hline $\begin{array}{l}\text { Group } 6 \text { - Theobromine Then Allowed For } 21 \\
\text { Days Without Treatment }\end{array}$ & $2.62 \pm 0.10^{\mathrm{b}}$ & $0.96 \pm 0.05^{\mathrm{a}}$ & $0.87 \pm 0.02^{\mathrm{ac}}$ & $1.27 \pm 0.15^{\mathrm{ac}}$ & $0.48 \pm 0.04$ \\
\hline
\end{tabular}

$\mathrm{a}=$ significantly different when compared to Group 1 at $\mathrm{P}<0.05 ; \mathrm{b}=$ significantly different when compared to Group 2 at $\mathrm{P}<0.05$; $\mathrm{c}=$ significantly different when compared to Group 4 at $\mathrm{P}<0.05$.

Table 2. Effect of Ethanol Leaf Extract of Vernonia amygdalina on Some Liver Enzyme Activities of Albino Wistar Rats Intoxicated with Theobromine.

\begin{tabular}{llll}
\hline GROUPS & AST (U/L) & ALT (U/L) \\
\hline Group 1 - Control & $97.00 \pm 1.00$ & ALP (U/L) & $18.60 \pm 0.51$ \\
Group 2 - Theobromine & $121.00 \pm 1.18^{\mathrm{a}}$ & $26.20 \pm 1.11^{\mathrm{a}}$ & $86.80 \pm 2.22^{\mathrm{a}}$ \\
Group 3 - V. Amygdalina & $109.20 \pm 0.86^{\mathrm{ab}}$ & $18.00 \pm 0.84^{\mathrm{b}}$ & $58.20 \pm 3.06^{\mathrm{ab}}$ \\
\hline
\end{tabular}




\begin{tabular}{llll}
\hline GROUPS & AST (U/L) & ALT (U/L) & ALP (U/L) \\
\hline Group 4 - Theobromine Then V. Amygdalina & $87.00 \pm 2.45^{\mathrm{ab}}$ & $18.20 \pm 0.37^{\mathrm{b}}$ & $53.00 \pm 1.76^{\mathrm{ab}}$ \\
Group 5 - V. Amygdalina Then Theobromine & $85.40 \pm 3.94^{\mathrm{ab}}$ & $16.80 \pm 0.80^{\mathrm{b}}$ & $49.60 \pm 1.78^{\mathrm{ab}}$ \\
Group 6 - Theobromine Then Allowed For 21 Days Without Treatment & $105.80 \pm 1.69^{\mathrm{abc}}$ & $21.60 \pm 0.51^{\mathrm{abc}}$ & $57.00 \pm 1.30^{\mathrm{ab}}$ \\
\hline
\end{tabular}

$\mathrm{a}=$ significantly different when compared to Group 1 at $\mathrm{P}<0.05 ; \mathrm{b}=$ significantly different when compared to Group 2 at $\mathrm{P}<0.05 ; \mathrm{c}=$ significantly different when compared to Group 4 at $\mathrm{P}<0.05$.

Table 3. Effect of Ethanol Leaf Extract of Vernonia amygdalina on Some Indices of Kidney Function in Albino Wistar Rats Intoxicated with Theobromine.

\begin{tabular}{llllll}
\hline GROUPS & Creatinine $(\boldsymbol{\mu m o l} / \mathbf{L})$ & Urea $(\mathbf{m m o l} / \mathbf{L})$ & $\mathbf{N a}^{+}(\mathbf{m m o l} / \mathbf{L})$ & $\mathbf{K}^{+}(\mathbf{m m o l} / \mathbf{L})$ & $\mathbf{C l}^{-}(\mathbf{m m o l} / \mathbf{L})$ \\
\hline Group 1 & $48.86 \pm 1.84$ & $2.50 \pm 0.17$ & $132.66 \pm 0.90$ & $6.84 \pm 0.46$ & $97.18 \pm 1.30$ \\
Group 2 & $56.60 \pm 1.54^{\mathrm{a}}$ & $3.56 \pm 0.21^{\mathrm{a}}$ & $133.94 \pm 1.4$ & $6.49 \pm 0.37$ & $95.34 \pm 1.70$ \\
Group 3 & $37.78 \pm 3.06^{\mathrm{ab}}$ & $2.72 \pm 0.15^{\mathrm{b}}$ & $136.66 \pm 1.46^{\mathrm{a}}$ & $6.79 \pm 0.21$ & $96.00 \pm 1.03$ \\
Group 4 & $45.20 \pm 0.87^{\mathrm{b}}$ & $3.12 \pm 0.19^{\mathrm{a}}$ & $137.88 \pm 0.53^{\mathrm{abc}}$ & $5.65 \pm 0.15^{\mathrm{ab}}$ & $96.08 \pm 0.52$ \\
Group 5 & $49.16 \pm 1.33^{\mathrm{b}}$ & $2.34 \pm 0.25^{\mathrm{bc}}$ & $138.46 \pm 0.60^{\mathrm{ab}}$ & $5.89 \pm 0.20^{\mathrm{a}}$ & $96.90 \pm 0.70$ \\
Group 6 & $59.36 \pm 1.53^{\mathrm{ac}}$ & $3.26 \pm 0.19^{\mathrm{a}}$ & $135.68 \pm 0.65$ & $5.77 \pm 0.16^{\mathrm{a}}$ & $97.36 \pm 0.63$ \\
\hline
\end{tabular}

$\mathrm{a}=$ significantly different when compared to Group 1 at $\mathrm{P}<0.05 ; \mathrm{b}=$ significantly different when compared to Group 2 at $\mathrm{P}<0.05 ; \mathrm{c}=$ significantly different when compared to Group 4 at $\mathrm{P}<0.05$.
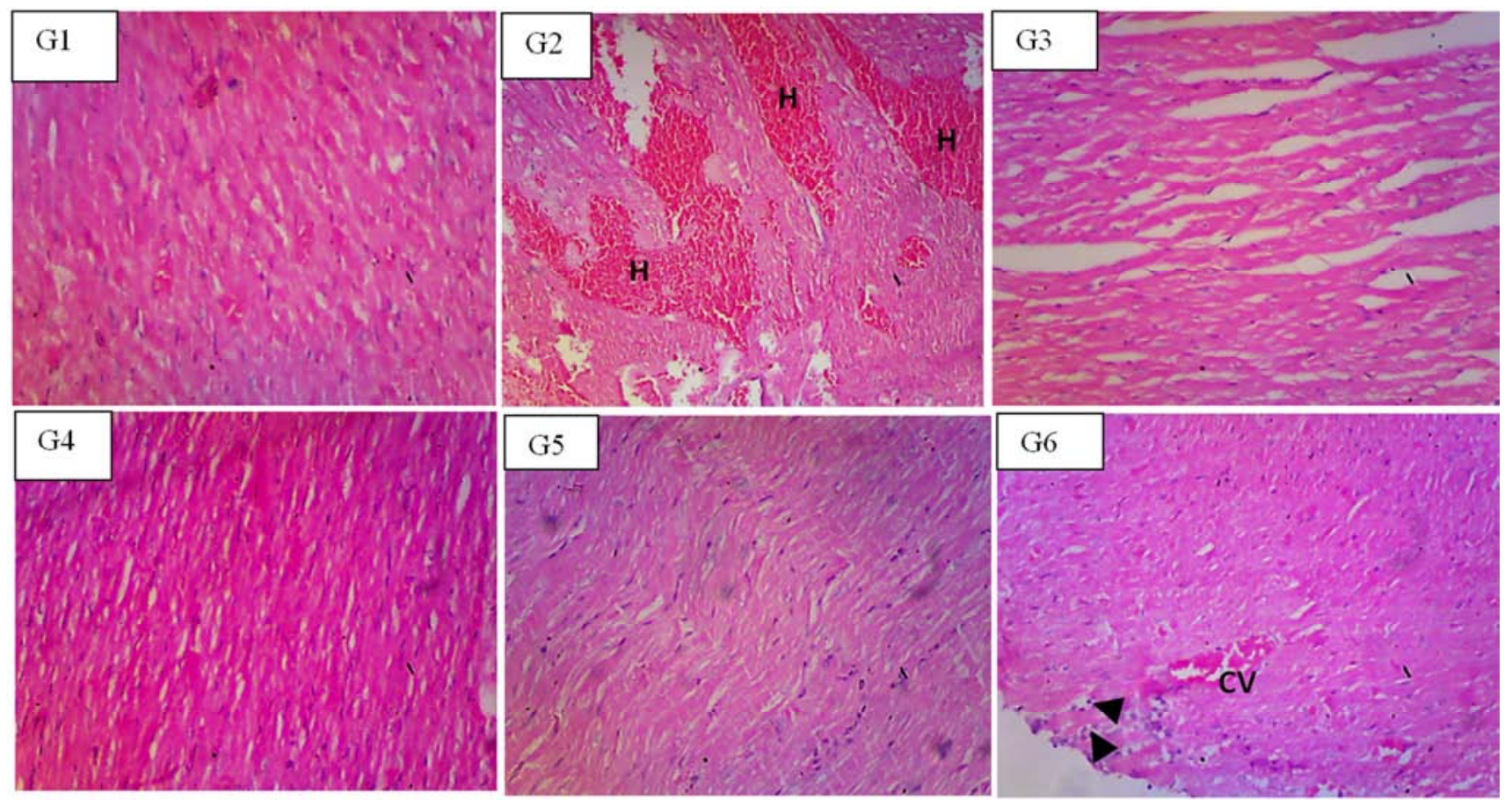

Figure 1. Photomicrographs of heart tissue of albino rats of Group 1 with normal cytoarchitecture of the heart (G1); Group 2 showed heart tissue with haemorrhage ( $\mathrm{Hg}$ ) permeating the myocardium and degeneration of cellular architecture (G2); Group 3 revealed normal histology of the heart (G3); Group 4 revealed normal histology of the heart (G4); Group 5 with normal histology of the heart (G5) and Group 6 showing congested blood vessels (V) and pericardium inflammation (arrow) (G6). H and E technique; Magnification $=x 100$

The concentrations of urea and creatinine were significantly elevated with theobromine intoxication when compared to the control group. Administration of Vernonia amygdalina significantly lowered the urea and creatinine concentrations in the treated groups compared to Group 2 but the Group 6 showed no significant reduction when compared to Group 2. The concentration of the electrolytes was not adversely affected by the treatments. Normal cytoarchitecture of the kidney was observed in the control group while Group 2 was observed with cellular degeneration and inflamed renal tubules. Distinct glomerulus and renal tubules were observed in Groups 3, 4 and 5 while mild glomerular degeneration and inflamed tubules are observed in Group 6. 

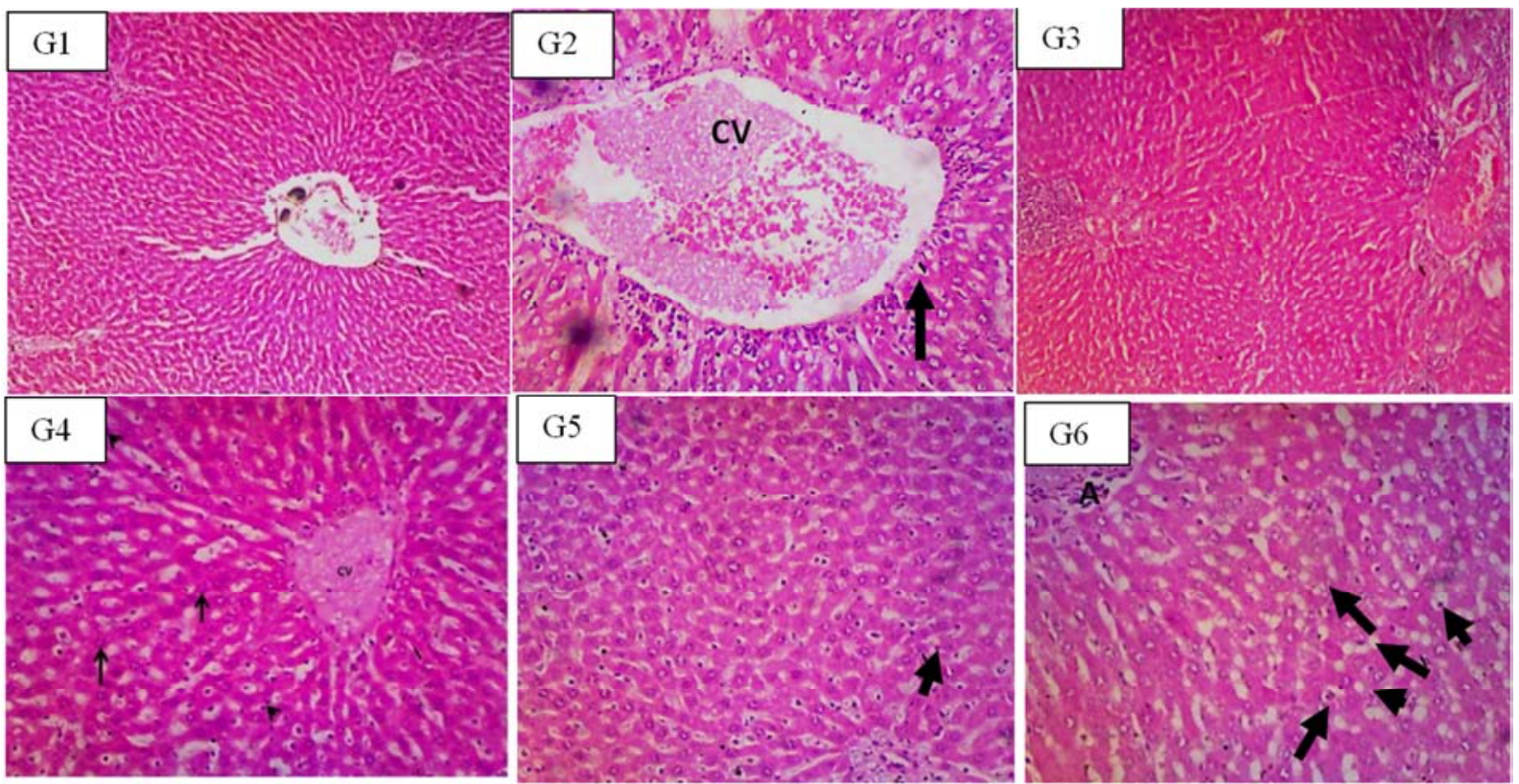

Figure 2. Photomicrographs of Liver of albino rats of Group 1 with normal cytoarchitecture of the liver (G1); Group 2 showed enlarged congested central vein (CV) and degeneration of cellular architecture (G2); Group 3 revealed normal histology of the liver (G3); Group 4 showing mildly distributed lobular and sinusoidal inflammation (arrow head) (G4); Group 5 with mononuclear inflammatory infiltrates (arrow) diffusely distributed in the parenchyma (G5) and Group 6 showing mononuclear inflammatory infiltrates (arrow) and widened sinusoid (G6). H and E technique; Magnification =x100.
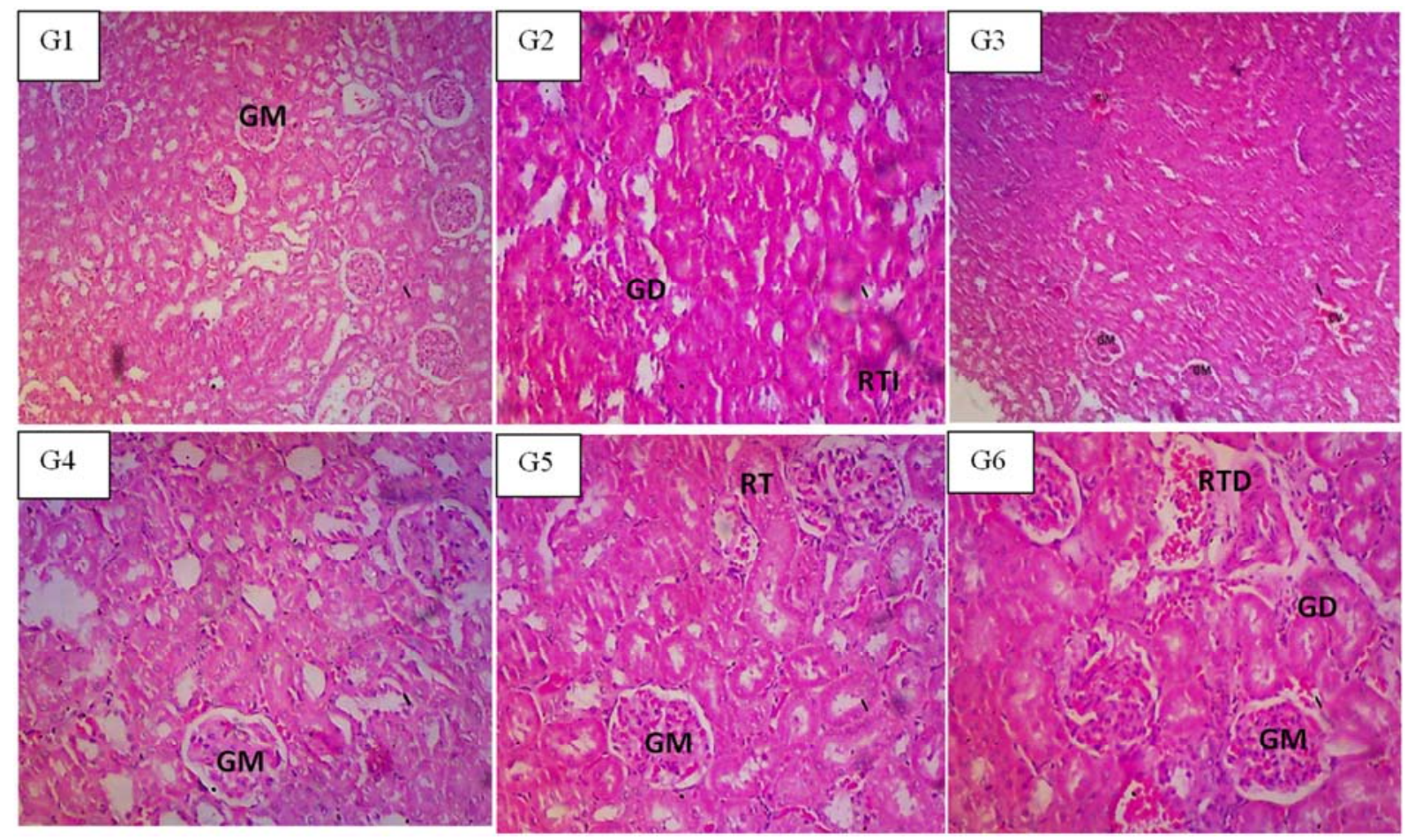

Figure 3. Photomicrographs of kidney of albino rats of Group 1 showed normal renal tissue cyto-architecture with distinct glomeruli and bowman's capsule (G1); Group 2 revealed degenerated glomeruli (GD) and renal tubular inflammation (RTI) (G2); Group 3 is evident with normal histomorphology of the kidney tissue (G3); Group; Group 4 revealed normal glomeruli with mild cellular degeneration (G4); Group 5 revealed normal renal tubules (RT) and glomeruli (GM) (G5); and Group 6 revealed glomeruli degeneration and renal tubular degeneration (G6).

\section{Discussion}

Theobromine is widely consumed in cocoa based products such as chocolate and other beverages. The toxicity of theobromine to the heart and liver has been established in experimental animals $[29,15]$. Other studies have reported the cardioprotective and hepatoprotective potentials of the leaf extract of Vernonia amygdalina $[12,10]$. The present study, therefore evaluated the effect of ethanol leaf extract of Vernonia amygdalina on some indices of cardiac, liver and kidney function in theobromine intoxicated animals. 
The present study demonstrated that serum liver enzymes (ALT, AST and ALP) were elevated following the administration of theobromine to the experimental animals. The liver is very susceptible to toxic effects from chemical substances due to its direct contact with these substances in an attempt to metabolize them. Hepatocyte membrane distortion is associated with membrane leakage of the hepatocyte cytosolic contents which is manifested by significant elevation of serum/plasma enzymes namely; ALT, AST and ALP [30]. The elevated activities of these enzymes in the present study is an indication of hepatic toxicity induced by theobromine. This result aligns with the report by Eteng et al., [15] in which AST and ALT activities were reported to be elevated in experimental animals following administration of theobromine. The histology of the liver obtained in the present study further establish the toxic effect of theobromine on the liver. Section of Liver architecture showed enlarged congested central vein (CV) and degeneration of cellular architecture (Figure 2: G2).

The administration of the ethanol extract of Vernonia amygdalina significantly decreased the activities of the hepatic enzymes which were increased due to theobromine administration. The administration of Vernonia amygdalina before and after theobromine administration was observed to protect the liver against and ameliorate theobromine induced hepatotoxicity in the experimental animals. Vernonia amygdalina has been reported to be hepatoprotective against carbon tetrachloride induced hepatotoxicity in albino rats [31]. The report suggests that extract of $V$. amygdalina leaf possess protective effect against $\mathrm{CCl}_{4}$-induced hepatotoxicity by the antioxidant mechanism of action. Recent report by Iwo et al., [32] also suggest hepatoprotective effect of Vernonia amygdalina against drug intoxicated male Wistar rats. Liver damage can be prevented by using hepatoprotective agents - compounds that mitigate liver damage caused by hepatotoxic agents. The administration of Vernonia amygdalina restored normal histological features in the cytoarchitecture of the liver which were damaged by theobromine administration. Another study where Vernonia amygdalina ameliorated damages caused to the liver by isoniazid and rifampicin combination [32] corroborates the result of the present study. In the present study, the liver enzymes ALT and AST were still observed to have elevated activities 21-days post theobromine administration without administration of the extract.

Theobromine and its derivatives act as smooth-muscle relaxants, diuretics, cardiac stimulants, and coronary vasodilators [33]. Dyslipidaemia is a known risk factor for cardiovascular diseases and is a common cause of morbidity and mortality even in developing countries [34]. Lipid lowering and cardioprotective effect of $V$. amygdalina has been reported [35]. The report documented that $V$. amygdalina reduced atherogenic index in experimental animal intoxicated with acetaminophen. Elevated concentration of total cholesterol and LDL-cholesterol and decreased concentration of HDL-cholesterol following administration of theobromine in the present study shows the negative modulation of lipid profile in the experimental animals. A combination of increased LDL-C and decreased HDL-C is known to be a contributing factor to atherogenesis and coronary artery disease [36].

Vernonia amygdalina is widely used for both its nutritional benefits and medicinal potential. The leaf extract of Vernonia amygdalina has been reported to have lipid-lowering effects in rats fed on a high cholesterol diet [37]. The present study has shown a significant decrease in the concentration of total cholesterol and LDL-C in $V$. amygdalina treated rats. This is in line with the findings of other studies [38, 39]. The administration of ethanol extract of Vernonia amygdalina before and after theobromine administration as in the present study shows its beneficial effect against the adverse effect of theobromine. The Vernonia amygdalina leaf extract shows good protective and ameliorative effect on the lipid profile against the toxic effect of theobromine. From the result presented in Table 1, natural recovery and restoration of normal lipid profile after theobromine administration has been shown not to be as effective as administration of Vernonia amygdalina leaf extract. This is evident in the high concentration of total cholesterol and LDL-C as well as low levels of HDL cholesterol observed in Group 6.

The histology of the heart of the experimental animals following administration of theobromine showed areas of inflammation, vascular congestion and cellular proliferation with pyknotic nucleus. Other reports corroborate these findings; particularly, Eteng et al., [15] had established that theobromine is toxic particularly to the heart tissues of experimental animals. Furthermore, theobromine is also suspected to induce right atrial cardiomyopathy after long term exposure [29]. However, following the administration of ethanol leaf extract of Vernonia amygdalina, normal cellular features were observed to be restored in the heart tissues of the experimental animals.

Plasma concentrations of waste substances such as urea and creatinine as well as electrolytes are the most commonly used indices to evaluate renal function. The kidney functions to eliminate waste substances and control fluid, electrolyte and acid-base balance [40]. Renal injury often results in the accumulation of waste substances in the blood as well as altered fluid homeostasis and acid-base balance. In the present study, the urea and creatinine concentration were significantly elevated following administration of theobromine. Similarly, the histology of the kidney tissue showed inflamed and degenerated cellular architecture with the administration of theobromine. Plasma levels of creatinine and urea are determined by the balance between their rate of synthesis and excretion although they are subject to a large number of variables [41]. Since they are eliminated through the kidney, kidney diseases would therefore affect and alter their concentration. Renal tubular inflammation and degenerated glomeruli present in the histology of the kidney of theobromine treated group reveals its toxicity to the kidney which was ameliorated following the administration of ethanol leaf extract of $V$. amygdalina.

The administration of Vernonia amygdalina before 
theobromine intoxication protected the kidney against theobromine induced toxicity while administration of the extract after theobromine toxicity ameliorated the toxic effect of the theobromine on the kidney. This is evident in the reduction in the elevated urea and creatinine concentration in the Vernonia amygdalina extract treated groups. The histological features of the kidney tissues corroborate the observed changes in the concentration of urea and creatinine. Normal histological features such as renal tubules and glomeruli were observed following administration of ethanol leaf extract of Vernonia amygdalina to theobromine intoxicated animals. Significant changes were not observed in the electrolytes concentration in the study except in the sodium ion concentration in groups treated with $V$. amygdalina compared to the control. These electrolytes are commonly monitored in clinical practice and can be used to evaluate symptoms and effectiveness of treatment of high blood pressure, heart failure, liver and kidney disease. Several conditions can lead to electrolyte imbalance; dehydration, ketoacidosis, cancer, renal diseases and injury [40]. Sodium and Potassium are the principal cations in extracellular intracellular fluids respectively in which their physiological Concentration is regulated by the kidneys [42]. Sodium and Potassium balance is usually maintained even in disturbances that cause major changes in kidney function [28]. Hypokalaemia can result in muscular weakness and cardiac arrhythmia whereas hyperkalaemia is a risk factor for cardiac arrest [42]. The elevated sodium ion concentration observed in $V$. amygdalina treated groups maybe due to the presence of high amount of sodium in the leaf of Vernonia amygdalina which has been reported in literature [43].

A wide array of phytochemicals (including anti-nutritional factors) has been shown to be present in Vernonia amygdalina. The presence of oxalates, phytates and tannins has been reported $[4,5]$. Stigmastane-type saponins such as vernoniosides [44], have been found abundantly in the leaves of Vernonia amygdalina. Some of the identified Sesquiterpene lactones are vernolide, vernodalol [45], vernolepin, vernodalin and hydroxyvernolide [46]. Reports have established the presence of flavonoids in the leaves of Vernonia amygdalina [6, 47]. Other phytochemicals present in the leaf of Vernonia amygdalina are terpenes, coumarins, phenolic acids, lignans, xanthones and anthraquinones [47]. These phytochemicals are believed to be responsible for the plethora of bio-activities possessed by the plant. These bioactive principles may act singly, or synergistically to produce the results for which the medicinal values of Vernonia amygdalina have been vigorously studied. A study by Owolabi et al., [48] further showed that both the ethanol and aqueous extracts of Vernonia amygdalina have potent antioxidant abilities.

\section{Conclusion}

In conclusion, the present study has demonstrated that ethanol leaf extract of Vernonia amygdalina protects the liver and heart of male albino wistar rats against theobromine induced toxicity as evidenced by its ability to reverse elevated activities of serum enzymes (ALT, AST and ALP). The extract also protects against kidney damage by restoring to normal values the theobromine induced increase in the serum concentrations of urea and creatinine. Dyslipidemia caused by the treatment of the experimental animals with theobromine was modulated by the ethanol leaf extract of Vernonia amygdalina. Additionally, the theobromine induced alterations in the histology of the liver, heart and kidney sections of the experimental rats were normalized following treatment with ethanol leaf extract of Vernonia amygdalina.

\section{References}

[1] Ojiako, O. A., Nwanjo, H. U. 2006. Is Vernonia amygdalina hepatotoxic or hepatoprotective? Response from biochemical and toxicity studies in rats. African Journal of Technology, 5 (18), 1648-1651.

[2] Igile, G. O., Oleszek, W., Jurzysta, M., Burda, S., Fanfunso, M., Fasanmade, A. A. 1994. Flavonoids from Vernonia amygdalina and their antioxidant activities. J. Agric. Food Chem., 42, 2445-2448.

[3] Bonsi, M. L. K., Osuji, P. O., Tuah, A. K., Umunna, M. N. 1995. Vernonia amygdalina as supplement of teff straw (Eragrostis tef) fed to Ethiopian Menz sheep. Agroforestry Syst., 31, 229-244.

[4] Ejoh, R. A., Nkonga, D. V., Innocent, G., Moses, M. C. 2007, Nutritional components of some nonconventional leafy vegetables consumed in Cameroun, Pakistan Journal of Nutrition 6, 712-714.

[5] Eleyinmi, A. F., Sporns, P., Bressler, D. C. 2008, Nutritional composition of Gongronem alatifolium and Veronica amygdaina, Nutrition and Food Science 38, 99-109.

[6] Udensi, E. A., Ijeh, I. I., Ogbonna, U. 2002. Effect of traditional processing on the phytochemical and nutrient composition of some local Nigerian leafy vegetables. J. Sci. Tech., 8, 37-40.

[7] Ijeh, I. I., Nwugo, V. O., Obidoa, O. 1996. Comparative studies on the nutritive, phytochemical and antimicrobial properties of two varieties of Vernonia amygdalina. Plant Prod. Res. Comm., 1, 71-75.

[8] Nwanjo, H. U. 2005. Efficacy of aqueous leaf extract of Vernonia amygdalina on plasma lipoprotein and oxidative status in diabetic rat models. Nig. J. Physiol. Sci., 20, 39-42.

[9] Ekpo, A., Eseyin, O. A., Ikpeme, A. O., Edoho, E. J. 2007. Studies on some biochemical effects of Vernonia amygdalina in rats. Asia J. Biochem., 2, 193-197.

[10] Asuquo, O., Igiri, A., Akpan, J. Akpaso, M. 2009. Cardioprotective potential of Vernonia amygdalina and Ocimum gratissimum against Streptozocin (STZ)- Induced Diabetes in Wistar rats. The Internet Journal of Tropical Medicine 7 (1).

[11] Arhoghro, E. M., Ekpo, K. E., Anosike, E. O., Ibeh, G. O. 2009. Effect of aqueous extract of bitter leaf (Vernonia amygdalina Del) on carbon tetrachloride (CCl4) induced liver damage in albino wistar rats. Eur. J. Sci. Res., 26, 115-123. 
[12] Iwalokun, B. A., Efedede, B. U., Alabi-Sofunde, J. A., Oduala, T., Magbagveola, O. A., Akinwande, A. I. 2006. Hepatoprotective and antioxidant activities of Vernonia amygdalina on acetaminophen-induced hepatic damage in mice. J. Med. Food., 9 (4), 524-530.

[13] Atangwho, I. J., Ebong, P. E., Eteng, M. U., Eyong, E. U., Obi, A. U. 2007. Effect of Vernonia amygdalina Del. leaf on kidney function of diabetic rats. Int. J. Pharmacol., 3, 143-148.

[14] Tarka, S. M., Jr. 1982. The Toxicology of Cocoa and Methylxanthines. Critical Reviews in Toxicology, 9 (4), 275 312 .

[15] Eteng, M. U., Ebong, P. E., Ettarh, R. R., Umoh, I. B. 1998. Aminotransferase Activity in Serum, Liver and Heart Tissue of Rats Exposed to Theobromine. Indian Journal of Pharmacology, (30), 339-342.

[16] Adeyina, A. O., Ogunteye, S. O., Olatunde, O. A., Apata D. F. 2008. Comparative Effects of Theobromine and Cocoa Bean Shell (CBS) Extract on the Performance, Serum constituent Profile and Physiological Parameters in Rabbits. Global Journal of Pure and Applied Science. 14 (3), 253-255.

[17] Bell, G. H., Emslien, S. D., Paterson, C. R. 1992. Textbook of Physiological and Biochemistry, Churchill Livingstone, Edinburg, pp 229-239.

[18] National Research Council. 1985. Guide for care and use of Laboratory Animals. Publication of the National Institute of Health. Bethesda, MD.

[19] Wroblewski, F., LaDue, J. S. 1956. Proceedings of the Society of Experimental Biology and Medicine, 91, 569.

[20] Doumas, B., Briggs, H. G. 1972. Standard Methods of Clinical Chemistry. London: Academic Press, New York. p175.

[21] Bowers, G. N., McComb, R. B. 1966. Continuous Spectrophotometric Method for Measuring the Activity of Serum Alkaline Phosphatase. Clinical Chemistry, 12, 70.

[22] Allain, S. C., Poon, L. S., Chan, C. S., Richmon, W. S., Fu, P. C. 1974. Enzymatic Determination of Total Serum Cholesterol. Clin. Chem., 20, 470-475.

[23] Lopes-Virella, M. F., Stone, P., Ellis, S., Colwell, J. A. 1997. Cholesterol Determinant in High Density Lipoproteins Separated by Three Different Methods. Clin. Chem., 23 (5), 882-884.

[24] Tietz, M. N. 1990. Clinical Guide to Laboratory Test. 2nd Ed. W. B. Saunders Company, Philadelphia, USA. pp. 554-556.

[25] Friedewald, W. T., Levy, R. I., Fredrickson, D. S. 1972. Estimation of the Concentration of LDL Cholesterol in Plasma, without use of the Preparative Ultra-Centrifuge. Clin Chem, 18, 499-502.

[26] Sampson, E. J., Baird, M. A. and Burtis, C. A. 1980. A Coupled Enzyme Equilibrium Method for Measuring Urea in Serum. Optimisation and Evaluation of the AACC Study Group on Urea Candidate Reference Method. Clinical Chemistry, 26: 816 - 826.

[27] Heinegard, D., Tiderstrom, G. 1973. Determination of Serum Creatinine by a Direct Colorimetric Method. Clinical Chemistry Acta, 43, 305 - 310.
[28] Akpanyung, E. O., Bassey, U. E., Usoh, I. F., Iba, I. U. 2015. Effect of Combined Administration of Artequin ${ }^{\circledR}$ and Pefloxacin on some Indices of Liver and Renal Functions of Male Albino Wistar Rats. Pharmacologyonline, 3, 84-90.

[29] Joseph, H. G. 1980. Effects of short-term and long-term theobromine administration to male dogs. Toxicology and Applied Pharmacology. 53 (3), 481-496.

[30] Bhaltacharya, M., Western, V., Pan, K. 2003. Elevation of serum/plasma enzymes of acute hepatocellular damage. Clinical Pharmacology and Therapeutics. 41 (7), 16-19.

[31] Adesanoye, O. A., Farombi, E. O. 2010. Hepatoprotective effects of Vernonia amygdalina (astereaceae) in rats treated with carbon tetrachloride. Experimental and Toxicological Pathology. 62 (2), 197-206.

[32] Iwo, M. I., Sjahlim, S. L., Rahmawati, S. F. 2017. Effect of Vernonia amygdalina Del. Leaf Ethanolic Extract on Intoxicated Male Wistar Rats Liver. Sciencia Pharmaceutica $85,16$.

[33] Windholz, M. 1983. The Merck Index, 10th ed., Rahway, NJ, Merck \& Co., p. 1327.

[34] World Health Organization (WHO). 2003. World Health Report 2003: Shaping the future. WHO Geneva, Switzerland, pp. 85-91.

[35] Egbung, G. E., Atangwho I. J., Odey, O. D., Ndiodimma V. N. 2017. The Lipid Lowering and Cardioprotective Effects of Vernonia calvoana Ethanol Extract in Acetaminophen-Treated Rats. Medicines (Basel). 4 (4), 90.

[36] Akpanyung, E. O., Ita, S. O., Opara, K. A., Davies, K. G., Ndem, J. I., Uwah, A. F. 2013. Phytochemical Screening and Effect of Ethanol Root extract of Microdesmis puberula on some haematological and biochemical parameters in normal male albino Wistar rats. Journal of Medicinal Plant Research, 7 (31), 2338-2342.

[37] Adaramoye, O. A., Akintayo, O., Achem, J., Fafunso, M. A. 2008. Lipid lowering effects of methanolic extracts of Vernonia amygdalina leaves in rats fed on high cholesterol diet. Vasc. Health Risk Manage., 4, 236-241.

[38] Egedigwe, C. A. 2010. Effect of dietary incorporation of Vernonia amygdalina and Vernonia colorata on blood lipid profile and relative organ weights in albino rats. MSc., Dissertation, Dept. Biochem., MOUAU, Nigeria.

[39] Ugwu, C. E., Ejike, C. E. C. C., Alumana, E. O., Ezeanyika, L. U. S. 2010. Comparative study on the effects of the leaves of Gongronema latifolium, Vernonia amygdalina and Telfairia occidentalis incorporated diets on the lipid profiles of rats. Ind. J. Anim. Nutr., In press.

[40] Chiasson, J. L., Aris-Jilwan, N., Belanger, R., Bertrand, S., Beauregard, H., Ekoe, J. M., Fournier, H., Havrankova, J. 2003. Diagnosis and treatment of diabetic ketoacidosis and the hyperglycemic hyperosmolar state. CMAJ 168 (7), 859-866.

[41] Griffin, K. A., Kramer, H., Bidani, A. K. 2008. Adverse renal consequences of Obesity. American Journal of Physiology Renal Physiology, 294, F685-F696.

[42] Burtis, C. A., Ashwood, E. R., Bruns, D. E. 2012. Tiez Fundamental of Clinical Chemistry, $6^{\text {th }}$ ed., Elsevier Publishers, India. 
[43] Sodamade, A. 2013. Proximate analysis, mineral content, amino acid composition and functional properties of Vernonia amydalina vegetable leaf protein concentrate. Greener Journal of Agricultural Sciences, 3 (3), 204-210.

[44] Jisaka, M., Ohigashi, H., Takagaki, T., Nozaki, H., Tada, T., Hiroto, M., Irie, R., Huffman, M. A., Nishida, T., Kagi, M., Koshimizu, K. 1992. Bitter steroid glucosides, vernoniosides A1, A2, A3 and related B1 from a possible medicinal plant Vernonia amygdalina used by wild chimpanzees. Tetrahedron, 48, 625-632.

[45] Erasto, P, Grierson, D. S., Afolayan, A. J. 2006. Bioactive sesquiterpene lactones from the leaves of Vernonia amygdalina. J. Ethnopharmacol., 106, 117-120.
[46] Koshimizu, K., Ohigashi, H., Huffman, M. A. 1994. Use of Vernonia amygdalina by wild chimpanzee: Possible roles of its bitter and related constituents. Physiol. Behav., 56, 12091216.

[47] Tona, L., Cimanga, R. K., Mesia, K., Musuamba, C. T., Bruyne, T. D., Apers, S., Hernans, N., van Miert, S., Pieters, L., Totté, J., Vlietinck, A. J. 2004. In vitro antiplasmodial activity of extracts and fractions from seven medicinal plants used in the Democratic Republic of Congo. J Ethnopharmacol. 2004, 93:27-32.

[48] Owolabi, M. A., Jaja, S. I., Oyekanmi. O. O., Olatunji, O. J. 2008. Evaluation of the antioxidant activity and lipid peroxidation of the leaves of Vernonia amygdalina. J. Compl. Integr. Med., 5, 10.2202/1550- 3840.1152. 